\title{
RESTORATION OF HEPATIC MITOCHONDRIA DURING RECOVERY FROM CARBON TETRACHLORIDE INTOXICATION
}

\author{
Michael J. Brabec, Robert H. Gray and I. A. Bernstein \\ Environmental Cellular Chemistry Laboratory of the Department of Environmental and \\ Industrial Health, and the Department of Biological Chemistry, The University of Michigan, \\ Ann Arbor, Mich. 48104, U.S.A.
}

(Received 28 October 1973; accepted 22 March 1974)

\begin{abstract}
During $\mathrm{CCl}_{4}$ intoxication in rats, a disruption of hepatic mitochondrial structure and function occurs, which is characterized by a loss of respiratory activity, loss of phosphorylation coupled to respiration, and mitochondrial swelling, attended by loss of cristae structure. Within 15-25 hr, after full development of the mitochondrial lesion, the function and structure of the mitochondria are largely restored. Studies of the turnover of mitochondrial DNA and the rates of synthesis of mitochondrial DNA and protein indicated that the $\mathrm{CCl}_{4}$-insulted hepatocyte is repairing the mitochondrial damage by the insertion of specific elements into the damaged organelle, rather than by proliferation of undamaged mitochondria for replacement. The failure of ethidium bromide, oxytetracycline and chloramphenicol, specific inhibitors of mitochondrial protein, and/or nucleic acid synthesis, to block this restoration substantiates the postulated repair process, and also indicates the non-critical nature of the respective mitochondrial functions during the repair process. Cytochrome measurements made during the period of acute damage revealed normal levels of cytochrome $c, c_{1}$ and $a a_{3}$. The observed elevation of cytochrome $b$ is attributed to contamination of the preparation by hemoglobin.
\end{abstract}

THE HEPATIC mitochondrion is one of the characteristic sites of $\mathrm{CCl}_{4}$-induced cell damage. ${ }^{1}$ Ultrastructurally, the mitochondria of an intoxicated animal appear to be swollen in situ, and the matrix is abnormally lucid. ${ }^{2}$ The mitochondria are calcium loaded, and amorphic, dense bodies, probably aggregations of calcium phosphate, are noted in the matrix of the swollen organelles. ${ }^{3}$ The altered in situ appearance is accompanied by a loss of respiratory activity, especially on $\mathrm{NAD}^{+}$-linked substrates, and by an impairment of energy-coupled functions, which is detectable when isolated mitochondria are assayed. ${ }^{4}$ This lesion is not necessarily associated with lethality, since the lesion can be developed by a dose of $\mathrm{CCl}_{4}$ from which the animal recovers. Under such conditions, mitochondrial degeneration ceases and a return of normal structure and function is observed.

Of interest to this laboratory is the route by which the $\mathrm{CCl}_{4}$-damaged hepatocyte affects the restoration of its damaged mitochondria. In consideration of recent proposals related to mitochondrial biogenesis, it is necessary to consider a minimum of three possible routes of restoration: (1) Replacement of damaged organelles. Since it is possible that all mitochondria within a surviving hepatocyte have not suffered massive damage, a replicative burst of mitochondrial biogenesis by the slightly damaged, or undamaged mitochondria could serve to replenish the mitochondrial 
population depleted by $\mathrm{CCl}_{4}$-induced destruction. (2) Repair of the damaged organelles. The $\mathrm{CCl}_{4}$-induced damage, while causing obvious mitochondrial derangements, might be localized in a relatively simple unit of the mitochondrion, amenable to repair by elements generated by the recovering hepatocyte. (3) Repair and replacement. A combination of both operations could repair the less damaged organelles, and replace those that have been irreversibly damaged. This study of the synthesis and turnover of mitochondrial elements during $\mathrm{CCl}_{4}$ intoxication, complemented with the use of selective inhibitors of mitochondrial protein and nucleic acid synthesis, was designed to indicate which of the above three mechanisms was responsible for restoration.

The data indicated that the restoration of the damaged organelles was primarily a repair process, not involving mitochondrial DNA, RNA or protein synthesis. However, a late acceleration in mitochondrial DNA turnover rates does indicate that mitochondrial replication can be occurring during the late phase of recovery. Normal levels of mitochondrial cytochromes were found, thereby tentatively eliminating these elements as being sites of $\mathrm{CCl}_{4}$-induced damage.

\section{MATERIALS AND METHODS}

Materials. Heavy metal-free sucrose, ADP, Tris and oligomycin were obtained from Sigma Chemical Co. Ethidium bromide, B grade, was purchased from Calbiochem. Chloramphenicol (Chloromycetin) was a generous gift from Mr. Stanley Kurtz of Parke, Davis \& Co. Oxytetracycline (Liquamycin) was purchased from Chas. Pfizer Co. Radioisotopes were obtained from New England Nuclear or SchwarzMann. PCS solubilizer (Schwarz-Mann) was used as a scintillation mixture for radioactivity determinations. Carbon tetrachloride was reagent grade, as were all other chemicals used. Solutions used for mitochondrial assay and isolation were prepared with double-distilled water.

Mitochondrial preparation and assays. Rats were 180-220 g males, CFN strain, reared in this laboratory's colony. $\mathrm{CCl}_{4}$ was injected i.p., without dilution, at $1.4 \mathrm{ml} /$ $\mathrm{kg}$. kater in the study, the level of $\mathrm{CCl}_{4}$ was reduced to $1.2 \mathrm{ml} / \mathrm{kg}$, which reduced the rate of early mortality without affecting the mitochondrial response. At desired intervals, the intoxicated rats were killed by stunning and decapitation, the liver, or a selected lobe, was removed, minced, rinsed and then homogenized in $0.25 \mathrm{M}$ sucrose, $1 \mathrm{mM}$ EDTA, $10 \mathrm{mM} \mathrm{KCl}$ and $10 \mathrm{mM}$ Tris $\left(\mathrm{pH} 7.0\right.$ at $0^{\circ}$ ). The homogenate was centrifuged at $450 \mathrm{~g}$ for $10 \mathrm{~min}$ to remove nuclei, unbroken cells and debri. The mitochondrial fraction was prepared from the post-nuclear supernatant by centrifugation at $8800 \mathrm{~g}$ for $10 \mathrm{~min}$. The mitochondrial pellet was resuspended in the original homogenate volume of $0.25 \mathrm{M}$ sucrose and centrifuged for $10 \mathrm{~min}$ at $480 \mathrm{~g}$. The supernatant was centrifuged at $7200 \mathrm{~g}$ for $10 \mathrm{~min}$. The resulting pellet was resuspended in $0.25 \mathrm{M}$ sucrose, and the $7200 \mathrm{~g}$ wash routinely repeated once except for those experiments that involved radioisotopes, in which case four additional $7200 \mathrm{~g}$ washes were performed. Aseptic techniques using sterile solutions were practiced in the L-leucine incorporation experiments in vitro to diminish the problem of bacterial contamination.

The mitochondria were assayed with an oxygen electrode apparatus in a 2-ml water-jacketed chamber stirred with a magnetic bar. The respiratory rate and respiratory control ratio (RCR) were determined essentially as described by Estabrook ${ }^{5}$ 
in a medium containing $0.15 \mathrm{M}$ sucrose, $20 \mathrm{mM} \mathrm{KH}_{2} \mathrm{PO}_{4}, 20 \mathrm{mM}$ Tris $(\mathrm{pH} 7.4$ at $25^{\circ}$ ), $5 \mathrm{mM} \mathrm{MgCl}_{2}$ and $100 \mathrm{mM}$ succinate. Oligomycin was added to a final concentration of $1 \mu \mathrm{M}$. Protein was determined by the Biuret method as modified by Jacobs et al. ${ }^{6}$ or by the procedure of Lowry et al. ${ }^{7}$

Inhibitor studies. Chloramphenicol, as the sodium succinate salt dissolved in water, was injected i.p., at a level of $200 \mathrm{mg} / \mathrm{kg}$ body weight every $6 \mathrm{hr}$, commencing $30 \mathrm{hr}$ after the injection of $\mathrm{CCl}_{4}$. Oxytetracycline was administered i.p., $100 \mathrm{mg} / \mathrm{kg}$, every $8 \mathrm{hr}$ beginning $30 \mathrm{hr}$ after $\mathrm{CCl}_{4}$ administration. Ethidium bromide, dissolved by warming in chloroform-saturated water, was injected i.p., $25 \mathrm{mg} / \mathrm{kg}$, twice daily, in a manner similar to chloramphenicol and oxytetracycline.

Mitochondrial DNA synthesis and turnover. Control and $\mathrm{CCl}_{4}$-intoxicated rats were injected with $250 \mu \mathrm{Ci} / \mathrm{kg}$ body weight of $\left[{ }^{3} \mathrm{H}\right]$ thymidine (sp. act. $30-50 \mathrm{Ci} / \mathrm{m}$ mole) at the selected intervals and the mitochondria isolated $30 \mathrm{~min}$ later, with the additional washes described above. The final pellet was dissolved in $4 \mathrm{ml}$ of $1 \%$ sodium deoxycholate (DOC), and the nucleic acids and protein were precipitated with $4 \mathrm{ml}$ of $0.5 \mathrm{~N}$ perchloric acid (PCA). A pellet was obtained by centrifuging for $5 \mathrm{~min}$ at $9000 \mathrm{~g}$. The pellet was washed twice by resuspension in $10 \mathrm{ml}$ of $0.5 \mathrm{~N}$ PCA. The supernatant of the second wash was essentially non-radioactive. The pellet was dissolved in $3 \mathrm{ml}$ of $88 \%$ formic acid and aliquots were removed for estimation of protein and for determination of radioactivity in a Packard Tri-Carb 3300 liquid scintillation counter. Counts/min were corrected to dis./min by use of an efficiencyquench curve, using the instrument's Automatic External Standard, based on an unquenched efficiency of 38.3 per cent for the scintillation mixture.

The mitochondrial DNA was labeled for the turnover studies by three i.p. injections of a total of $170 \mu \mathrm{Ci}\left[{ }^{3} \mathrm{H}\right]$ thymidine administered at 2 -hr intervals. ${ }^{8} \mathrm{CCl}_{4}$ was administered to the rats $2 \mathrm{hr}$ after the last $\left[{ }^{3} \mathrm{H}\right]$ thymidine injection. At the indicated time intervals, pairs of animals were sacrificed, and the mitochondria isolated as above, precipitated and washed by the above protocol, dissolved in $0.4 \mathrm{~N} \mathrm{KOH}-1 \%$ sodium dodecylsulfate (SDS), and the radioactivity and protein determined on duplicate aliquots, as above.

$\mathrm{L}-\left[{ }^{14} \mathrm{C}\right]$ leucine incorporation, in vitro. Mitochondria were isolated aseptically from control and intoxicated rats with the additional washes as described above. The assay for $\mathrm{L}-\left[{ }^{14} \mathrm{C}\right]$ leucine incorporation was carried out as described by Simpson $e t$ al., ${ }^{9}$ except that the incubation period was shortened to $20 \mathrm{~min}$. Mitochondria (10 $\mathrm{mg}$ protein $/ \mathrm{ml}$ ) were incubated in $0.15 \mathrm{M}$ sucrose, $3 \mathrm{mM} \mathrm{KCl}, 1 \mathrm{mM}$ EDTA, $8 \mathrm{mM}$ succinate, $12 \mathrm{mM} \mathrm{KH}_{2} \mathrm{PO}_{4}, 3 \mathrm{mM} \mathrm{AMP}, 3.5 \mathrm{mM} \mathrm{NAD}, 6 \mathrm{mM} \mathrm{MgSO} \mathrm{m}_{4}$ (pH 7.0), complete amino acid mixture (minus L-leucine) and L- $\left[{ }^{14} \mathrm{C}\right]$ leucine (sp. act. $300-326$ $\mathrm{Ci} /$ mole) at $30^{\circ}$. Bacterial contamination was monitored by plating $0.05 \mathrm{ml}$ of incubation mixture on nutrient agar plates immediately after the assay and incubating for $24 \mathrm{hr}$ at $37^{\circ}$. Experiments that yielded over 1000 colonies $/ \mathrm{ml}$ were discarded.

$\mathrm{L}-\left[{ }^{14} \mathrm{C}\right]$ leucine incorporation, in vivo. Control and $\mathrm{CCl}_{4}$-intoxicated groups of rats were given $250 \mu \mathrm{Ci} / \mathrm{kg}$ body weight L- $\left[{ }^{3} \mathrm{H}\right]$ leucine (sp. act. $53 \mathrm{Ci} / \mathrm{m}$-mole) i.p. at the time period of interest. Sixty min later, the animals were sacrificed, paired livers pooled, and the mitochondria were isolated as described above. The final pellet was suspended in $0.1 \mathrm{M}$ Tris ( $\mathrm{pH} 8.0)-0.1 \mathrm{M} \mathrm{NaCl}, 1 \%$ SDS, then precipitated with $10 \%$ trichloroacetic acid (TCA)-0.05 M L-leucine, collected at $2000 \mathrm{~g}$, extracted once with $5 \% \mathrm{TCA}$, dissolved in $1 \mathrm{~N} \mathrm{NaOH}$, reprecipitated with $10 \%$ TCA-0.05 M L-leucine, 
sedimented, and finally dissolved in $2 \mathrm{~N} \mathrm{NaOH}$. Aliquots were removed for protein determination and scintillation counting. An aliquot of the final TCA supernatant was also monitored for radioactivity.

Electron microscopy. Tissue was finely minced, fixed in $3 \%$ glutaraldehyde- $0 \cdot 2 \mathrm{M}$

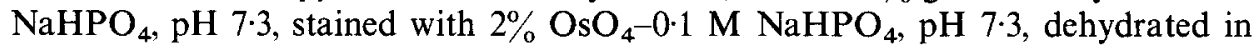
ethanol and propylene oxide and embedded in Epon. Thin sections were obtained with a Reichart OMU-2 ultramicrotome equipped with a diamond knife, placed on carbon-coated Formvar grids, post-stained with Reynolds lead citrate ${ }^{10}$ and $7 \%$ uranyl magnesium acetate, and examined in an AEI Corinth electron microscope.

Cytochrome assays. Mitochondrial cytochrome content was measured by difference spectroscopy on DOC-solubilized mitochondria with an Aminco DW-2 spectrophotometer operated in the split-beam mode as described by Williams. ${ }^{11}$

\section{RESULTS}

Progression of the mitochondrial lesion. Hepatic mitochondria were prepared and assayed in an oxygen electrode at various times after a single i.p. injection of $\mathrm{CCl}_{4}$ $(1.4 \mathrm{ml} / \mathrm{kg}$ body weight). The loss and recovery of respiratory activity and respiratory control are shown in Fig. 1. This is essentially the same pattern as reported by Thiers et al., ${ }^{4}$ Recknagel and Anthony ${ }^{12}$ and Cohn et al. ${ }^{13}$ We refer to the period from 35 to $45 \mathrm{hr}$ as "acute damage," the period from 45 to $60 \mathrm{hr}$ as "early recovery" and the period from 60 to $100 \mathrm{hr}$ as "late recovery." It can be seen that, during the acute state of damage, rates of succinate oxidation are 50 per cent of control levels. Rates of glutamate oxidation (not shown) are even lower. The respiratory control ratio falls drastically, as a result of both a decline in the rate of State 3 (ADP-stimulated) and an increase in the State 4 (ADP-depleted) respiration rate. The damage to the coupling mechanism implied by the increase in State 4 respiration rates is further substantiated by a low sensitivity to oligomycin (an inhibitor of coupled respiration) in the damaged mitochondria.

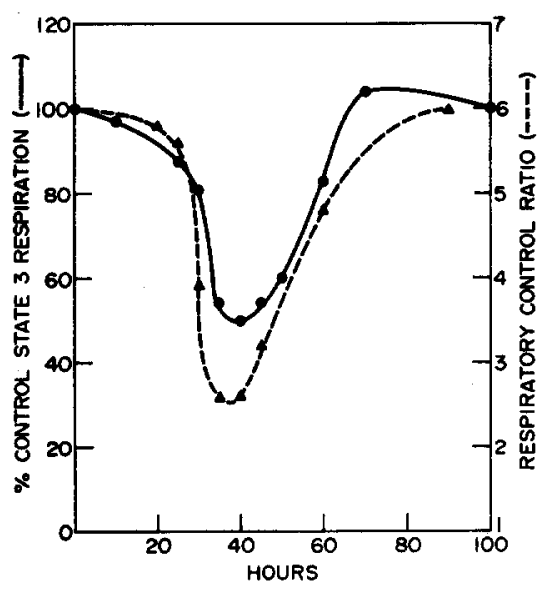

FIG. 1. Course of the mitochondrial lesion during $\dot{\mathrm{CCl}}_{4}$ intoxication, as reflected by the State 3 (ADPstimulated) respiration rate $(\bullet)$, and respiratory control ratio [ $\mathbf{\Delta}$, the ratio of ADP-stimulated (State 3$)$ to ADP-depleted (State 4) respiration rates]. $\mathrm{CCl}_{4}, 1.4 \mathrm{ml} / \mathrm{kg}$, was injected at zero time. The mitochondria were prepared and assayed as described in Materials and Methods in an oxygen electrode apparatus. Each point represents the average value of at least three animals. 
Mitochondrial DNA synthesis and turnover. Hepatic mitochondria possess a circular naked DNA molecule and the appropriate enzymes for its replication and transcription. ${ }^{14}$ It is implicit in models of mitochondrial biogenesis that proliferation of mitochondria be accompanied by replication and distribution of DNA among the newly formed mitochondria. Thus, if extensive mitochondrial proliferation occurs as part of recovery from $\mathrm{CCl}_{4}$ intoxication, mitochondrial DNA should show increased synthesis and/or turnover. In this case, mitochondrial DNA replication might also be a particularly sensitive point of the recovery process.

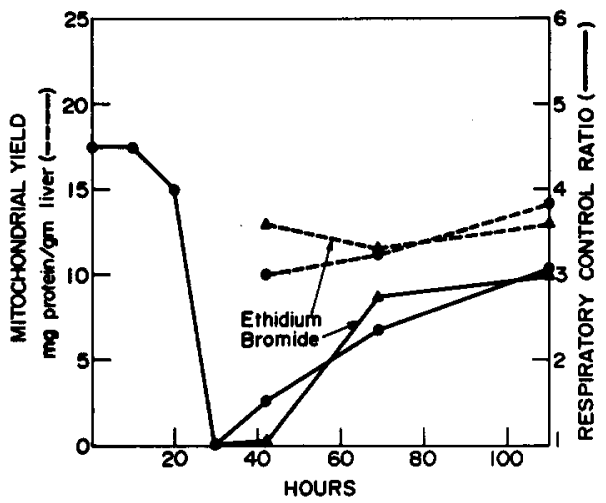

FIG. 2. Restoration of mitochondria during $\mathrm{CCl}_{4}$ intoxication in the presence and absence of $25 \mathrm{mg} / \mathrm{kg} /$ day of ethidium bromide (administration commencing at arrow). Mitochondria were prepared and assayed for respiratory control as in Fig. 1 (solid lines). Mitochondrial yield is expressed as the total mitochondrial protein isolated divided by the net wet weight of the intact liver. Two to eight animals were studied in each time period.

To test this latter possibility, we treated intoxicated rats with ethidium bromide during recovery. Ethidium bromide is capable of interposing between the two strands of naked DNA in such a manner as to block replication and transcription of the DNA. ${ }^{15}$ Administering ethidium bromide at $25 \mathrm{mg} / \mathrm{kg}$ body weight to control rats would cause a 42 per cent reduction in the incorporation of $\left[{ }^{3} \mathrm{H}\right]$ thymidine into acidinsoluble mitochondrial fractions, when the isotope was injected $6 \mathrm{hr}$ after the drug. When this level of ethidium bromide was injected into intoxicated rats, twice daily, no alteration in the recovery of RCR or yield of mitochondria could be ascertained (Fig. 2). Thus, a considerable disruption of mitochondrial DNA replication and transcription can be tolerated during recovery. The relatively minor rate of mitochondrial DNA synthesis during this period is also indicated by the depression of $\left[{ }^{3} \mathrm{H}\right]$ thymidine incorporation into mitochondrial DNA in vivo during the period of acute damage and early recovery (Fig. 3). $\left[{ }^{3} \mathrm{H}\right]$ thymidine incorporation approached control rates after $60 \mathrm{hr}$ of intoxication.

Although the data indicate that mitochondrial DNA synthesis is greatly depressed during the periods of acute damage and early recovery $(35-60 \mathrm{hr})$ and that mitochondrial DNA synthesis is not critical to recovery, the mitochondria might be replicating using pre-existing copies of DNA, since several copies of DNA are thought to coexist within a mitochondroin, ${ }^{14}$ and these multiple genomes could be a reservoir for emergency mitochondrial replication. If so, the turnover of mitochondrial DNA should increase during recovery at a rate sufficient to supply new organelle structures 


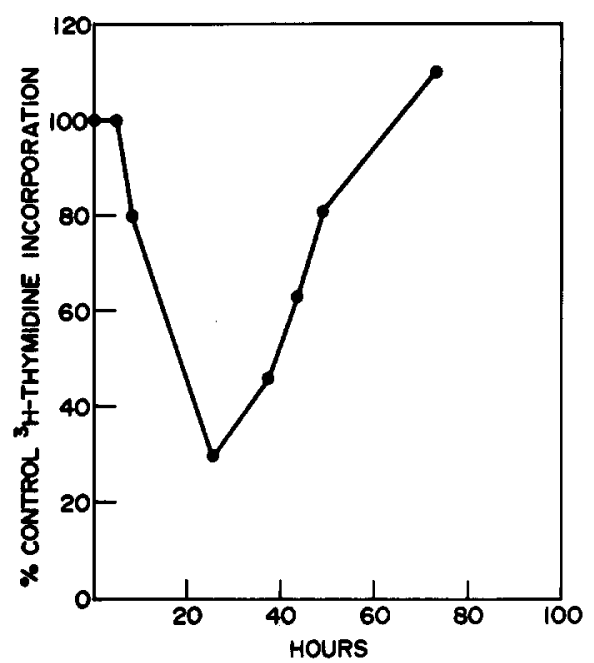

FIG. 3. Incorporation of $\left[{ }^{3} \mathrm{H}\right]$ thymidine into acid-insoluble mitochondrial material during $\mathrm{CCl}_{4}$ intoxication. Rats (either control or intoxicated) were injected 30 min prior to sacrifice with $250 \mu \mathrm{Ci} / \mathrm{kg}$ of $\left[{ }^{3} \mathrm{H}\right]$ thymidine, and the mitochondria were prepared and the specific radioactivity was determined as described under Materials and Methods. A total of 20 animals were used in the experiments.

to replace the $\mathrm{CCl}_{4}$-damaged entities. When mitochondrial DNA was pre-labeled with $\left[{ }^{3} \mathrm{H}\right]$ thymidine prior to $\mathrm{CCl}_{4}$ intoxication, it was found that mitochondrial DNA turnover exhibited a distinct biphasic response (Fig. 4). Turnover essentially stopped during the first $50 \mathrm{hr}$ of intoxication, and then accelerated. The rate of turnover of control mitochondrial DNA measured by this procedure ( $132 \mathrm{hr})$ is a value intermediate between that reported by Gross et al. ${ }^{8}(225 \mathrm{hr})$ and that reported by Dall$\operatorname{man}^{16}(117 \mathrm{hr})$. Since the data are expressed as ${ }^{3} \mathrm{H}$ dis. $/ \mathrm{min} / \mathrm{mg}$ mitochondrial protein, it should reflect the amount of mitochondrial DNA per mitochondrion, in a condition of little DNA synthesis. The decline of specific activity beginning at $50 \mathrm{hr}$

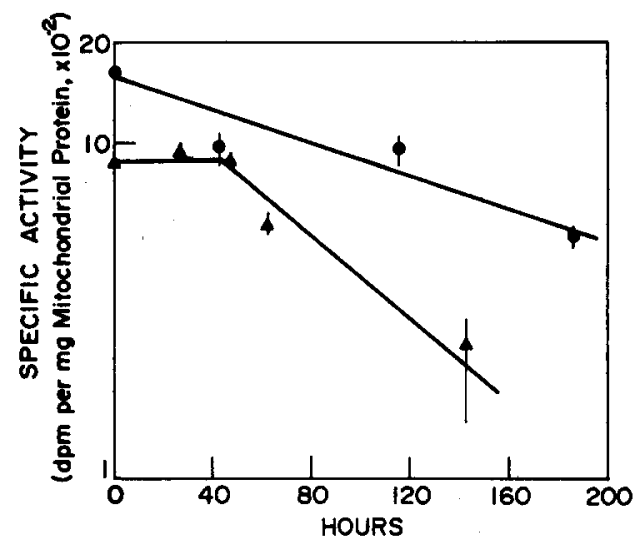

FIG. 4. Turnover of hepatic mitochondrial DNA (expressed as dis./min/mg of mitochondrial protein) in control and $\mathrm{CCl}_{4}$-intoxicated rats. The mitochondrial DNA was pre-labeled with $150 \mu \mathrm{Ci}\left[{ }^{3} \mathrm{H}\right]$ thymidine, and the specific activity determined as in Fig. 3. The half-life for the control animals (upper curve) is 132 $\mathrm{hr}$ and for the intoxicated animals (lower curve) is $42 \mathrm{hr}$, in the 40- to 150 -hr period. Each point represents an average value, with the range indicated. 
is coincident with the return toward normal mitochondrial DNA synthesis rates (cf. Figs. 3 and 4). Thus, some mitochondrial replication, as measured by this criteria, could be occurring during the later phase of restoration.

Protein synthesis. Mitochondrial biogenesis should involve protein synthesis; repair mechanisms need not, depending upon the nature of the lesion. Thus, it would be useful to know the relative levels of mitochondrial protein synthesis during recovery from $\mathrm{CCl}_{4}$. This was studied by injecting intoxicated animals with $\mathrm{L}-\left[{ }^{3} \mathrm{H}\right]$ leucine at selected times, and preparing and determining the specific activity of the mitochondrial fraction (Fig. 5). In accordance with the reports of Smuckler et al., ${ }^{17}$ protein synthesis is markedly depressed during the first $15 \mathrm{hr}$ of intoxication. A "peak" of label incorporation was observed between 30 and $40 \mathrm{hr}$., which precedes any observable or measurable functional restoration. When mitochondria were isolated, and incubated in the amino acid incorporation mixture described by Simpson et al., ${ }^{9}$ the rates of amino acid incorporation in vitro essentially reflected the functional integrity of the isolated mitochondria, as indicated by their respiratory control ratios.

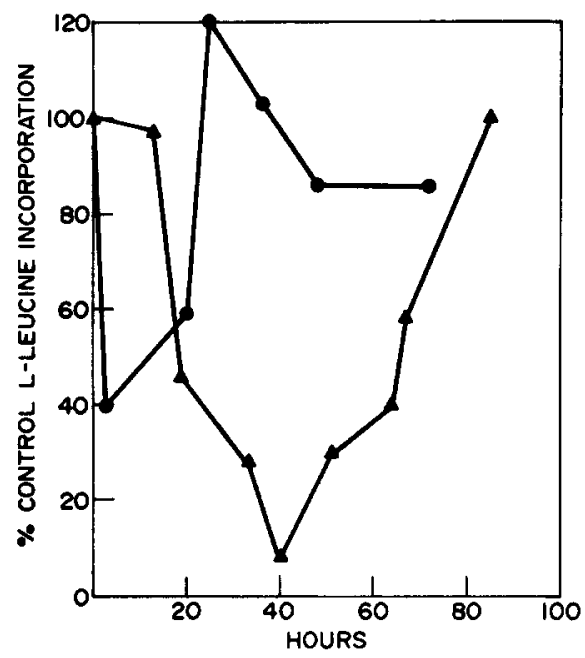

FIG. 5. Incorporation of L-leucine into mitochondrial proteins. In vivo (⿶): $\mathrm{CCl}_{4}$-intoxicated rats received $250 \mu \mathrm{Ci} / \mathrm{kg}$ of $\left[{ }^{3} \mathrm{H}\right]$ leucine i.p. $60 \mathrm{~min}$ prior to sacrifice. Mitochondria were prepared, and the specific radioactivity was determined as described in Materials and Methods. In vitro (A): mitochondria were prepared from two pooled livers aseptically, and incubated with L- $\left[{ }^{14} \mathrm{C}\right]$ leucine as described in Materials and Methods.

The proteins that comprise the mitochondria have two sites of synthesis, either on cytoplasmic ( $80 \mathrm{~S}$ ) ribosomes, or on mitochondrial (60S) ribosomes, i.e. extra-or intramitochondrial sites. ${ }^{18}$ Current estimates indicate that about 90 per cent of the mitochondrial protein complement arises on the $80 \mathrm{~S}$ ribosomes. In the study of $\mathrm{L}$ $\left[{ }^{3} \mathrm{H}\right]$ leucine incorporation in vivo, the incorporation of $\mathrm{L}-\left[{ }^{3} \mathrm{H}\right]$ leucine represents the contribution from both the cytoplasmic and mitochondrial protein synthetic systems. However, protein synthesis by the mitochondrial $60 \mathrm{~S}$ ribosome is selectively inhibited by the antibiotics chloramphenicol and oxytetracycline, while the cytoplasmic $80 \mathrm{~S}$ system is unaffected. ${ }^{19}$ Therefore, if the peak seen in the incorporation of tracer in vivo includes a significant contribution by the mitochondrial (60S ribosome) 
protein-synthesizing system to the restoration of the mitochondrion, restoration should be disrupted by an inhibitor of this system.

Chloramphenicol, injected i.p. (at a dose of $200 \mathrm{mg} / \mathrm{kg}$ body weight every $6 \mathrm{hr}$ commencing after $30 \mathrm{hr}$ of intoxication), did not delay the restoration of mitochondria in the recovering animal, as judged by measurement of respiratory control ratios in isolated mitochondria. Although some workers ${ }^{20,21}$ have reported that this dose regimen (or less) would maintain serum levels of chloramphenicol inhibitory to hepatic mitochondrial protein synthesis, the rapid conjugation and clearance of chloramphenicol might be permitting some mitochondrial protein synthesis to occur. ${ }^{19}$ Therefore, oxytetracycline was administered at $100 \mathrm{mg} / \mathrm{kg}$ body weight, thrice daily, in a similar study. This treatment has been reported to maintain satisfactory inhibitory levels of the antibiotic. ${ }^{22}$ This was confirmed by the following experiment. Control animals, sacrificed $30 \mathrm{~min}$ after the injection of $100 \mathrm{mg} / \mathrm{kg}$ of oxytetracycline, yielded mitochondria that showed a 70 per cent inhibition of $\mathrm{L}-\left[{ }^{14} \mathrm{C}\right]$ leucine incorporation in vitro relative to untreated controls. Eight hr after oxytetracycline, the inhibition had declined to 90 per cent of control levels. Failure to achieve 100 per cent inhibition may be a result of loss of the antibiotic during the extensive washing of the mitochondria during their preparation. (Addition of $100 \mu \mathrm{g} / \mathrm{ml}$ of oxytetracycline to the assay media completely inhibited incorporation.)

Mitochondria isolated from $\mathrm{CCl}_{4}$-intoxicated rats that had received $100 \mathrm{mg} / \mathrm{kg}$ of oxytetracycline every $8 \mathrm{hr}$, commencing at $30 \mathrm{hr}$ of intoxication, were assayed for respiratory control. No significant differences in respiratory control ratios were seen between mitochondria which had, and those which had not, received oxytetracycline during recovery from $\mathrm{CCl}_{4}$ intoxication (Table 1). Electron micrographs of hepatocytes from rats allowed to recover from intoxication in the presence of oxytetracycline did not show any aberrant mitochondrial profiles (Fig. 6).

Cytochrome levels. Spectral analysis (Table 2) of mitochondria isolated at $40 \mathrm{hr}$ of intoxication indicated that little change in cytochrome $a_{3}, c$ and $c_{1}$ levels had occurred during $\mathrm{CCl}_{4}$ intoxication. The only significant change observed in cytochrome levels was an increase in cytochrome $b$ in the damaged mitochondria. However, $\mathrm{CCl}_{4}$ increases the fragility of red cells, and extensive lysis accompanies $\mathrm{CCl}_{4}$ intoxication ${ }^{1}$ thus, it is likely that hemoglobin contaminated the damaged mitochondrial preparation. Hemoglobin (as does cytochrome b) possesses ferroprotoporphyrin IX

TABLE 1. EFFECT OF CHLORAMPHENICOL AND OXYTETRACYCLINE ON THE RECOVERY OF RESPIRATORY CONTROL BY HEPATIC MITOCHONDRIA AFTER $\mathrm{CCl}_{4}$ INTOXICATION*

\begin{tabular}{cccc}
\hline $\left.\begin{array}{c}\text { Time } \\
(\text { post-CCl }\end{array}\right)$ & $\mathrm{CCl}_{4}$ & $\begin{array}{c}\text { Respiratory control ratio }( \pm \mathrm{S} \text {. D.) } \\
\mathrm{CCl}_{4}+\text { chloramphenicol } \\
(200 \mathrm{mg} / \mathrm{kg})\end{array}$ & $\begin{array}{c}\mathrm{CCl}_{4}+\text { oxytetracycline } \\
(100 \mathrm{mg} / \mathrm{kg})\end{array}$ \\
\hline $46-51$ & $3.5 \pm 0.82$ & $3.3 \pm 0.94$ \\
$(6)$ & $3.13 \pm 0.71$ & $3.05 \pm 0.28$ & $(3)$ \\
$(6)$ & $(4)$ & $2 \cdot 73 \frac{0.76}{(6)}$ \\
\hline
\end{tabular}

* Intoxicated rats were given the indicated antibiotic either every $6 \mathrm{hr}$ (chloramphenicol) or every $8 \mathrm{hr}$ (oxytetracycline) beginning at $30 \mathrm{hr}$ post- $\mathrm{CCl}_{4}$ administration. At the indicated periods of recovery, the mitochondria were prepared and their respiratory control values determined using succinate as a substrate. Differences in the respiratory control ratios were not significant by two-tailed Student's $t$-test $0 \cdot 10$ level of significance. The number of animals is given in parentheses. 
TABLE 2. COMPARISON OF CYTOCHROME LEVELS IN HEPATIC MITOCHONDRIA ISOLATED FROM CONTROL AND $\mathrm{CCl}_{4}$-INTOXICATED RATS $\left(40 \mathrm{hr} \mathrm{CCl}_{4}\right.$ INTOXICATION)*

\begin{tabular}{|c|c|c|c|c|c|}
\hline \multirow[t]{2}{*}{ Animal group } & \multirow[t]{2}{*}{ Number } & \multicolumn{4}{|c|}{ Cytochrome levels, (nmoles/mg \pm S. D.) } \\
\hline & & $\mathrm{aa}_{3}$ & $\mathrm{~b}$ & $\mathrm{c}$ & $\mathrm{c}_{1}$ \\
\hline Control & 6 & $0 \cdot 240 \pm 0.041$ & $\begin{array}{c}0.250 \pm 0.054 \dagger \\
(1.04)\end{array}$ & $\begin{array}{c}0.153 \pm 0.016 \\
(0.64)\end{array}$ & $\begin{array}{c}0.165 \pm 0.028 \\
(0.69)\end{array}$ \\
\hline $\mathrm{CCl}_{4}(40 \mathrm{hr})$ & 13 & $0.228 \underset{(1)}{ \pm} 0.040$ & $\begin{array}{c}0.307 \pm 0.050 \dagger \\
(1.35)\end{array}$ & $\begin{array}{c}0.158 \pm 0.023 \\
(0.69)\end{array}$ & $\begin{array}{c}0.168 \pm 0.024 \\
(0.74)\end{array}$ \\
\hline
\end{tabular}

* Mitochondria were isolated as in Fig. 1, dissolved in $0.05 \mathrm{M} \mathrm{NaHPO}_{4}(\mathrm{pH} 7.0)$ and $2 \% \mathrm{DOC}_{\text {. The }}$ oxidized vs reduced spectrum was determined by split-beam spectrometry according to Williams. ${ }^{11}$ The number in parentheses is the ratio of the cytochrome to cytochrome $\mathrm{aa}_{3}$.

+ Significant at the 0.02 level of Student's $t$-test.

as a prosthetic group, and would, therefore, contribute to the $563-577 \mathrm{~nm}$ value, artificially raising the cytochrome $\mathrm{b}$ measurement. A decrease in cytochrome $\mathrm{c}$ has been reported in rat liver mitochondria during $\mathrm{CCl}_{4}$ intoxication. ${ }^{23}$ However, we failed to find a decrease, which coincides with the reports of Reynolds et al., ${ }^{24}$ and Lyachovich $e t$ al. ${ }^{25}$ who found no stimulation of respiration when cytochrome $\mathrm{c}$ is added to mitochondria from $\mathrm{CCl}_{4}$-intoxicated rats. Normal levels of cytochrome c oxidase activity have been found in $\mathrm{CCl}_{4}$-damaged mitochondria. ${ }^{25}$

Chloramphenicol or oxytetracycline has been shown to impair the synthesis or assembly of cytochrome c oxidase in yeast, ${ }^{26} \mathrm{HeLa}$ cells ${ }^{27}$ and regenerating rat liver. $^{20,22}$ The above discussion indicates that it is unlikely that any alteration of cytochrome components is induced by $\mathrm{CCl}_{4}$. Therefore, at least when considering the cytochromes, mitochondrial protein synthesis would not be required during restoration of the $\mathrm{CCl}_{4}$-damaged mitochondria, as has already been indicated by the failure of chloramphenicol and oxytetracycline to block recovery.

\section{DISCUSSION}

The molecular nature of the hepatic mitochondrial lesion induced by $\mathrm{CCl}_{4}$ is not known. Some authors believe it to be the result of peroxidation of the phospholipids of the mitochondrial membrane. ${ }^{25,28}$ Others have indicated that the unnatural distribution of ions in the $\mathrm{CCl}_{4}$-damaged hepatocyte would be sufficient to disrupt mitochondrial structure and function. ${ }^{3}$ Because it is not an early failure in $\mathrm{CCl}_{4}$ intoxication, but rather occurs after other pathologies are well developed, the mitochondrial lesion seems to be an indirect consequence of $\mathrm{CCl}_{4}$ exposure. However, the cessation of mitochondrial DNA turnover and synthesis (Figs. 3 and 4) immediately after administration of $\mathrm{CCl}_{4}$ indicates an early mitochondrial response to intoxication. Whether the cessation of mitochondrial DNA synthesis contributes to the further development of the mitochondrial lesion, or represents a general conservatory response of the cell to trauma cannot be decided from the data.

The cessation of mitochondrial DNA turnover would seem to rule out any extensive involvement of mitochondrial DNA replication in the early phase of recovery, although the turnover rate would allow consideration of some replication in the late recovery phase. It can be seen from the State 3 respiration rates in Fig. 1 that at 40 hr post- $\mathrm{CCl}_{4}$ either 50 per cent of the mitochondria are nonfunctional, or, conversely, 
all mitochondria have sustained 50 per cent damage. Thus, at least one half of the population would have to be replaced within the 40 - to $65-\mathrm{hr}$ period to allow recovery. The DNA turnover time of the $\mathrm{CCl}_{4}$ intoxicated animals, $42 \mathrm{hr}$, is too long to allow this to occur. Also, if mitochondrial DNA replication were critical to recovery, administration of ethidium bromide should have impeded recovery. It did not do so. Thus, insofar as mitochondrial proliferation can be judged from the turnover and synthesis of mitochondrial DNA, it does not seem to be a major route of restoration during early recovery.

The burst of incorporation of $\mathrm{L}-\left[{ }^{3} \mathrm{H}\right]$ leucine in vivo at about $30 \mathrm{hr}$ of intoxication suggests an involvement of protein synthesis in restoration. Since a large majority of mitochondrial proteins are synthesized on cytoplasmic ribosomes, ${ }^{18}$ it can be reasoned that most of this observed incorporation represents proteins synthesized on microsomal (80S), not mitochondrial (60S), ribosomes. The failure of oxytetracycline, ethidium bromide and chloramphenicol to interfere with mitochondrial recovery also supports the contention that mitochondrial protein synthesis is not involved in early recovery. It is possible that the short biological half-life of chloramphenicol could allow a small amount of mitochondrial protein synthesis to occur (although the extensive disruption of the endoplasmic reticulum by $\mathrm{CCl}_{4}{ }^{1}$ should depress the metabolism of chloramphenicol and prolong the drug's efficacy), and this could be sufficient for recovery. However, inhibitors of greater potency and persistence, oxytetracycline and ethidium bromide, similarly failed to delay or inhibit recovery. A more likely explanation is that the restoration of the $\mathrm{CCl}_{4}$-induced mitochondrial lesion does not require a contribution from mitochondrial protein synthesis. Chloramphenicol and ethidium bromide are also reported to distort mitochondrial profiles in growing HeLa and L-cell cultures. Electron micrographs did not reveal any distorted mitochondrial configurations in the hepatocyte at late recovery.

It may seem paradoxical that mitochondrial protein synthesis is not required to repair an extensively damaged mitochondrion. However, studies with regenerating rat liver after partial hepatectomy, ${ }^{21,22}$ and mammalian cell cultures ${ }^{19,27,29}$ showed that inhibitory levels of chloramphenicol, oxytetracycline or ethidium bromide did not cause a decrease of mitochondrial volume or numbers after one cell division. In all cases, a decline of cytochrome c oxidase, with its associated cytochrome $\mathrm{aa}_{3}$, was noted. It has been reported that three proteins in purified yeast cytochrome c oxidase are most likely of mitochondrial origin. ${ }^{30}$ Since in our experiments the spectral analysis did not indicate a loss of cytochromes in the damaged mitochondria, a locus for inhibitory action by chloramphenicol, oxytetracycline and ethidium bromide would not be present and, therefore, the failure of these drugs to inhibit restoration was not surprising.

The low rate of respiration present in $\mathrm{CCl}_{4}$-damaged mitochondria cannot be attributed to a loss of cytochrome components, as these were found to be present in normal amounts. However, oxidative phosphorylation and electron transport activities have been correlated with the structural configuration of mitochondria. ${ }^{31}$ Mitochondrial swelling, induced by NADPH oxidation, accompanied by oxidation of mitochondrial unsaturated lipids, results in inactivation of electron transport activity. ${ }^{32}$ Mitochondria during $\mathrm{CCl}_{4}$ exposure are noted to be swollen. ${ }^{3}$ This suggests that the impaired respiration rate is a result of the alterations in the mitochondrial membrane coincident with $\mathrm{CCl}_{4}$-induced mitochondrial swelling. 
Applying the data to the consideration of the routes of restoration, leads to the following conclusions. Route 1 , replacement, seems ruled out by the insufficiency of the mitochondrial DNA turnover rate, and the failure of ethidium bromide to block restoration. Route 2 , repair, must be considered, although the inhibitor data would indicate a non-critical role for mitochondrial protein synthesis. The peak of labeled leucine incorporation noted at $30 \mathrm{hr}$ implies the involvement of cytoplasmic protein synthesis. To fully accommodate the mitochondrial DNA turnover and synthesis data, and the decrease in mitochondrial yield noted at the nadir of damage, some replication must be invoked. This process must occur late in restoration and at a rate low enough to be accomplished in the face of incomplete inhibition by chloramphenicol, ethidium bromide and oxytetracycline. It appears, therefore, that restoration of mitochondrial integrity in the $\mathrm{CCl}_{4}$-damaged hepatocyte proceeds first (and predominantly) by repair of the less-damaged organelles, followed later by the replacement of the more-damaged, through replication of healthy mitochondria.

Acknowledgement - This work was partially supported by Graduate Research Training Grant in Cellular Chemistry and Physiology TOl AM 05268, and Research Training Grant in Toxicology ES00106, National Institutes of Health. During this investigation, Dr. Brabec was a National Institutes of Health post-doctoral Fellow, No. FO2 ES44255. The assistance of Roberta K. Brabec with the electron microscopy is gratefully acknowledged.

\section{REFERENCES}

1. R. O. Recknagel, Pharmac. Rev. 19, 145 (1967).

2. M. BASSI, Expl Cell Res. 20, 313 (1960).

3. E. S. ReYnolds, J. Cell Biol. 25, 53 (1965).

4. R. E. Thiers, E. S. Reynolds and B. L. VALleE, J. biol. Chem. 235, 2130 (1960).

5. R. W. Estabrook, in Methods in Enzymology (Eds. R. W. Estabrook and M. E. Pullman), p. 41. Academic Press, New York (1967).

6. E. E. JaCOBS, M. JACOB, D. R. SANAdi and L. B. Bradley, J. biol. Chem. 223, 147 (1956).

7. O. H. Lowry, N. J. Rosebrough, A. L. Farr and R. J. Randall, J. biol. Chem. 193, 265 (1951).

8. N. J. Gross, G. S. Getz and M. Rabinowitz, J. biol. Chem. 244, 1552 (1969).

9. M. V. Simpson, M. J. Fournier and D. M. Skinner, in Methods in Enzymology (Eds. R. W. EstaBrook and M. E. Pullman), p. 755. Academic Press, New York (1967).

10. E. S. ReynoldS, J. Cell Biol. 17, 208 (1963).

11. J. N. Williams, Biochim. biophys. Acta 162, 175 (1968).

12. R. O. ReCKNAGEL and D. D. ANTHONY, J. biol. Chem. 234, 1052 (1959).

13. D. V. Cohn, R. Dawdon, R. R. Newman and J. W. Hamilton, J. biol. Chem. 243, 1089 (1968).

14. P. Borst, in Control of Organelle Development (Ed. P. L. MiLler), p. 201. Academic Press, New York (1970).

15. M. M. K. Nass, Proc. natn. Acad. Sci. U.S.A. 67, 1926 (1970).

16. P. R. Dallman, J. Cell Biol. 51, 549 (1971).

17. E. A. Smuckler, O. A. Iseri and E. Benditt, Biochem. biophys. Res. Commun. 5, 270 (1961).

18. D. S. Beattie, Subcell. Biochem. 1, 1 (1971).

19. A. M. Kroon and H. DeVriEs, in Control of Organelle Development (Ed. P. L. Miller), p. 181. Academic Press, New York (1970).

20. F. C. Firkin and A. W. LinNANe, Expl Cell Res. 55, 68 (1969).

21. N. F. Gonzalez-Cadavid, E. M. A. Billo and J. L. RamiRez, Biochem. J. 118, 577 (1970).

22. H. DeVries and A. M. Kroon, Biochim. biophys. Acta 204, 531 (1970).

23. M. U. DiAnZANi and I. ViTi, Biochem. J. 59, 141 (1955).

24. E. S. Reynolds, R. E. Theirs and B. L. ValleE, J. biol. Chem. 237, 3546 (1962).

25. V. V. Lyachovich, V. M. Mishin, A. V. Dolgov, G. S. Jakobson, A. V. Panov and I. B. Tsyrlov, Biochem. Pharmac. 20, 1443 (1971).

26. C. P. Görts and A. HASILIK, Eur. J. Biochem. 29, 282 (1972).

27. M. E. King, G. C. Godman and D. W. KING, J. Cell Biol. 53, 127 (1972).

28. K. S. Rao and R. O. Recknagel, Expl molec. Path. 9, 271 (1968). 
29. R. LenK and S. Penman, J. Cell Biol. 49, 541 (1971).

30. T. L. Mason and G. SCHATZ, J. biol. Chem. 248, 1355 (1973).

31. C. R. Hackenbrock, T. G. Rehn, E. C. Weinbach and J. J. LeMasters, J. Cell Biol. 51,123 (1971).

32. P. M. Pfeifer and P. B. MCCAY, J. biol. Chem. 247, 6763 (1972). 